ROCZNIKI TEOLOGICZNE

Tom LXVIII, zeszyt $2-2021$

DOI: $\overline{\text { https://doi.org/10.18290/rt21682-5 }}$

MIKOŁAJ GRZENKOWITZ

\title{
THE RELATIONSHIP BETWEEN THEOLOGY AND LAW ON THE BASIS OF THE ENCYCLICAL PACEM IN TERRIS OF JOHN XXIII
}

\begin{abstract}
A bstract. The above research permits one to draw legal and theological conclusions. The first sub-point, presenting the legal value and social-political context of the papal teaching, permits the creation of a foundation for the following theological considerations. The second subpoint permits for the separation of the theology of the encyclical and its meaning for the whole document. The last sub-point reveals in what way the legal and theological elements intersect in the encyclical's text and what consequences this has for ecclesiology and the methodology of research at the intersection of theology and law. This article presented many mutual points of reference for theology and law and emphasized their methodological and substantive autonomy. The encyclical Pacem in terris of John XXIII is a creative proposal for the cooperation between theology and law, in which the Pope follows the principle of efficacy, which is the desire that the catalogue created by him is not only theoretical but also actually used. His teaching focuses on the theme of peace, which seems to assume the meaning that has already placed on justice, and the Pope seems to make it the centre of all international relations. That, in turn, allows to distinguish peace as a clearly legal category and so decisive for the just character of law itself. Because of the connection between peace, God's order and Christ's mission, there is a perfect intersection between temporal matters regulated by law and supernatural ones, which are the subject of theology. There exist two alternative models of the unity of humankind: the natural and the ecclesial. They have a complementary character as the two paths leading to a common goal and take the form of attaining the commonly desired peace on earth and the unification of humanity in Christ, who is peace himself. The Pope uses legal language, which has characteristics manifesting the openness of theology to law and vice-versa. Among them are cognitive realism, universal concepts, universal themes, social efficacy, legal naturalism, and mutual inspiration.
\end{abstract}

Keywords: law; theology; peace; John XXIII; Pacem in terris; methodology.

Mikołaj Grzenkowitz-graduate of theology at the John Paul II Catholic University of Lublin; e-mail: mikolaj.grzenkowitz@gmail.com 
The relationship between theology and law has a long history. The law, which organizes social life and secures the good of each human being, appears as a phenomenon of universal extent in time and space. It is also relevant as a historical concept, and even an object of religious belief, which makes law of interest not only to the social sciences, but also to philosophy and theology. Similarly, theology, which remains in an essential and dynamic relationship to Revelation, can be viewed as interested in a broad spectrum of human affairs. Therefore, law and theology are in special and constantly evolving bond. Modern theology realizes that it cannot be closed within its own limitations and, to communicate effectively the truth of Christian faith, it must go beyond its own language to create a space for dialogue with other fields of science. It is worth remembering that theology is one of the basic tools of the Church and that all theological research must be subordinate to its essence and purposes. That is why the search for new areas of research for theology is a step towards adjusting the dialogue between the Church and the outside world. Although scientific research at the intersection of theology and law is nothing new, both fields of science are subject to the continuous process of evolution, as well as their mutual subject and bond between them. It is also worth noting that the theology of law, as a separate branch of science, was established only in the middle of the 20th century. ${ }^{1}$

In this article, the issues of mutual relations between theology and law as scientific disciplines will be discussed. Both sciences, if not presented narrowly, have ample space for dialogue at the starting point, but their cooperation requires developing a well-thought methodology and setting directions for its development. A very inspiring source for this task seems to be the encyclical Pacem in terris of John XXIII in which the Pope discusses the conditions of building international peace, using both legal and theological language.

\section{LAW AND PEACE}

The encyclical Pacem in terris has great legal value. The Pope perceives interpersonal relationships in terms of rights and duties, as well as multilevel structures, which finds is reflected in the terminology he uses. The

\footnotetext{
${ }^{1}$ Remigiusz Sobański, Nauki podstawowe prawa kanonicznego, vol. 2: Teologia prawa kościelnego (Warszawa: Wydawnictwo Uniwersytetu Kardynała Stefana Wyszyńskiego, 2001), 9-10.
} 
teaching of a legal nature included in the encyclical is clear and forms a considered system, which determines the structure of the document. John XXIII proposes and discusses the principles of social order between individuals and within the state, as well as international peace, which is secured by the world-wide community of nations. He emphasizes the truth that every human being is truly a person, which means he is endowed with intelligence and free will, and as such he has rights and duties, which determine the order between persons. The basis of papal considerations in the encyclical is the philosophical concept of the law of nature, which justifies the request that the order of relationships between the individuals takes the shape of obeying the law and performing one's duties, which both are innate, universal, inviolable, and inalienable. ${ }^{2}$ This teaching is inseparably connected to the international situation in the tensest period of the Cold War and to the legislative activity of the world-wide community of nations.

The first chapter of the encyclical contains a "new declaration of human rights," 3 which is similar to these introduced through the international treaties of the United Nations. The rights enumerated by the Pope include a wide range of human life, which remains linked to the actions of other people, and to a greater or lesser extent refer to all main aspects of it. It allows protecting human good in a possibly complex way. This catalogue forms an orderly and considered system, which raises its prestige and even more increases the level of the legal protection of personal goods, which is proposed to individuals. The statements of the Pope witness that the Church in its conception of human rights include features of ethics, proportionality, and equity. For the interpretation of the encyclical's message, the frequently emphasized category of effectiveness appears to be relevant. It expresses the will of the Pope that his teaching be not only theoretical but be actually used.

In Pacem in terris, every mentioned right has a corresponding duty. The system of the law of nature appears as granting rights, prescribing duties, and being the beginning, the substance, and the source of absolutely binding power for both. ${ }^{4}$ The rights and duties are connected so strictly, that only the performance of duties allows exercising the rights. Through the combination of three components: rights, duties, and the natural human tendency to asso-

\footnotetext{
2 Jan XXIII, Encyclical Pacem in terris, 9.

${ }^{3}$ Ibidem, 11-27; Czesław Strzeszewski, Katolicka nauka społeczna (Warszawa: Wydawnictwo ODiSS, 1985), 297.

${ }^{4}$ Jan XXIII, Pacem in terris, 28.
} 
ciate, there arises the common social life and the attainment of the good for others. This is a social guarantee for respecting the rights and performance of duties, as well as a specific system, to which creation it is necessary to establish those social relations, which would have a guaranteed value. Society must be effective in its tasks and organized to ensure this effectiveness, because the law itself is dead, if not guaranteed by socially constituted duty. ${ }^{5}$ It cannot be forgotten that personal dignity requires individual responsibility from each person but also a protection of individual freedom from society. The observance of the law, performance of duties, and cooperation must originate from the free will of humans ${ }^{6}$. It is also worth noting that the Pope primarily understands the law as Latin ius, treating it as the right, the essence of which is the protection of individuals ${ }^{7}$.

John XXIII presents the universal moral order, which applies to all nations on every level of social relationships. When it comes to the internal order of the state, it is identified with the organization of the social life on the institutions of authority. The Pope claims that authority is a condition for the existence and action of society because it is intended to effectively persuade citizens to act on behalf of the common good. The only reason for the existence of authority is its guarantee function, which justifies its power of commitment and ordering. ${ }^{8}$ The second chapter of the encyclical gives the anthropological definition of Pius XII, which is the basis for the legal considerations: "an autonomous being, the subject of duties and inviolable rights, and the origin and purpose of human society." It is thus emphasized that human has not only intelligence and free will but is also a social creature. So defined, man still needs the state, as a necessary community, to ensure his rights and duties in function of his fundamental features as a social being. From the papal document, there also emerges an interesting concept of personification of society, as an abstract being, in its capacity for personal acts, which are reasonable and free, precisely on account of the establishment of such authority.

\footnotetext{
${ }^{5}$ Ibidem, 31.

${ }^{6}$ Ibidem, 34.

${ }^{7}$ Witold Wołodkiewicz, “'Ius et lex’ w rzymskiej tradycji prawnej,” Ius et Lex no. 1 (2002), 51-61.

${ }^{8}$ Jan XXIII, Pacem in terris, 47.

${ }^{9}$ Pius XII, "Orędzie radiowe wygłoszone w wigilię Bożego Narodzenia 1944 r.," AAS 37 (1945), 15, quoted after Jan XXIII, Pacem in terris, 47.
} 
Multi-level social order, which is discussed by John XXIII, cannot exhaust itself only as order between individuals and order within the state. This is due to the simple fact that these fields alone are not capable to exercise their guarantee function for respecting human rights and duties. It is also viewed that the existence of nations is not isolated but remains linked to the life of other nations and therefore takes the form of international interdependence. The nations have their own rights and duties towards each other and should direct themselves through the law of nature in the matter of regulating their mutual relationships. ${ }^{10}$ The reason for that conclusion might be a previous observation that, through its human authorities, the nation in some way becomes a collective person. This authority represents the society and acts on behalf of its good, and it is always bound by the norms of the law of nature. ${ }^{11}$ The strongest and the most radical call of the Pope is that global peace requires people to remove fear and arm themselves in trust. Disarmament must be universal and complex but first needs to take its place in human consciousness. Only the ruling of the law of rational human nature based on truth, justice, and solidarity can make the war useless in the matter of regulating international relations. ${ }^{12}$ Peace, as a universal desire of humanity, must be stable, inviolable and, what is crucial, guaranteed. For it is the source of the good of individuals, nations, and the whole human family. ${ }^{13}$ In the teaching of John XXIII, peace can perform the function of the foundation of the friendship between nations based on trust, honesty, and fidelity. This requirement seems to put on peace the whole meaning of justice and make it the centre of all international relations. That allows treating peace as the legal category, which decides about the just character of law itself.

The greatest value of the encyclical Pacem in terris seems to be the proposal of establishment of the world-wide community of nations. It is supposed to be the ultimate level of every social relationship, whose internal order is discussed by John XXIII, and to be a goal, which is necessary to accomplish, because of its most effective guarantee of rights and duties of the individuals and nations. There comes about a new global community, which is created by the people, so it cannot be deprived of its qualification within the law of nature. John XXIII notes that modern processes of integration taking place

\footnotetext{
${ }^{10}$ Ibidem, 80.

${ }^{11}$ Ibidem, 81

12 Ibidem, 113.

${ }^{13}$ Ibidem, 116.
} 
within humanity are not surprising and they can be subject to human thought. The Pope teaches that the world-wide human community is something natural, based on the universal human dignity, and has truly existed from the very beginning of humankind, but only in the modern period has it begun to take visible shape, what is seen through these processes of integration. In this context, John XXIII performs an ultimate identification of the common good and identifies it with the good of all human family, which gives the global size to all human rights and duties, both in their understanding as the space of their realization and the order which guarantees them. Carrying about all humanity belongs then to human nature. ${ }^{14}$ Repeatedly emphasized in the encyclical, the warrant of being effective demands the establishment of universal public authority, which can guarantee this good. The existence of a sufficiently powerful, organized, and equipped world-wide authority is for the Pope not only the practical requirement but also a warrant of the law of reasonable human nature. ${ }^{15}$

The pontificate of John XXIII lasted for the first years of the post-Stalin period when the repercussions of World War II were still alive, and the Cold War had just begun. Humanity, which had not arisen yet after the tragedy of World War II, was all the time in the pain of multiple conflicts and violence. The Cold War period should be considered as the time of global fear of conflict which consequences will be incomparably worse than these of World War II. In this matter, the Catholic Church pronounced her teaching in the critical moment of the year 1963. The encyclical Pacem in terris appeared within five months after the blockade of Cuba and four months before the signing of an agreement in Moscow prohibiting nuclear tests. ${ }^{16}$ The Pope himself took a part in the diplomatic actions on behalf of the dissolution of this last tension between the global powers, and his encyclical is considered as a voice on behalf of reconciliation between the East and the West in the name of protecting the world from the cruelty of global war. ${ }^{17}$

The negative context of the encyclical, which was a rising tension in international relations, should be seen together with its positive counterpart,

\footnotetext{
${ }^{14}$ Ibidem, 132.

15 Ibidem, 137.

${ }^{16}$ Roman Lusawa, "Encyklika 'Pacem in terris' - głos Kościoła katolickiego w sprawie pokoju z 11 kwietnia 1963 roku," Rocznik Naukowy Wydziału Zarządzania w Ciechanowie 4, no. 1-4 (2010): 104-5.

${ }^{17}$ John N.D. Kelly, Encyklopedia papieży, trans. Tadeusz Szafrański (Warszawa: Państwowy Instytut Wydawniczy, 2006), 451.
} 
which was rising global cooperation for protecting world-wide peace. John XXIII himself emphasizes in Pacem in terris that the most significant effort on behalf of this cooperation is recognized as the creation and action of the United Nations, especially the Universal Declaration of Human Rights. The Pope says: "Nevertheless, We think the document should be considered a step in the right direction, an approach toward the establishment of a juridical and political ordering of the world community. It is a solemn recognition of the personal dignity of every human being [...]."18 This document is an enumeration of the rights and fundamental freedoms of individuals. It was proclaimed as a "goal to be sought by all peoples and all nations." The main aspect of this document is an affirmation of innate human dignity, as well as the equal and inalienable rights of all people, as the foundation of freedom, justice, and world-wide peace. ${ }^{19}$

\section{THEOLOGY AND PEACE}

The encyclical Pacem in terris is a document of the Magisterium, in which John XXIII exercises his universal authority of teaching. The reason for the encyclical's publication as well as its content permits us to allows one to distinguish its primarily theological meaning. This theology is focused on the three key concepts, namely: the vision of God's order at the beginning of the encyclical; the action of God and the supernatural context, which penetrate the entirety of the encyclical, as well as the pastoral exhortations at in the fifth chapter. The encyclical flows directly from the teaching of his papal predecessors, especially Pius XII, but it also introduces some new ideas, namely, openness toward the world and a greater foundation in revelation.

In Pacem in terris, the Pope sketches the theological vision of the order of creation established by God. This vision is significant for the dialogue between law and theology because there exists a direct bond between the will of God and laws made by humans. In the introduction, "Order in the Universe," the encyclical clearly emphasizes that God is the only creator of

\footnotetext{
${ }^{18}$ Jan XXIII, Encyclical Pacem in terris, 144.

${ }^{19}$ Powszechna Deklaracja Praw Człowieka [Universal Declaration of Human Rights], accessed June 8, 2020, https://www.unesco.pl/fileadmin/user_upload/pdf/Powszechna_Deklaracja_Praw_ Czlowieka.pdf.
} 
the cosmic order. That means that the universe, taken as the whole of creation, is permeated by God's will. The second part of the introduction, "Order in Human Beings," describes how God's order is also present inside man as a law existing deeply in his heart and conscience which grasps this law. In the third part of the introduction, "Order between Men," the Pope says that the laws of nature are different from the law of rational human nature, which should govern social relations. Man is a participant of God's order in creation as part of the natural world but also as independent from it, because this order is given to him but not in any way binding his rational will. This task obviously requires previous preparation, and the Pope sees the law of rational human nature as fulfilling this role. In the introduction, there is thus revealed the multiformity of this order given by God, which is possible to express in the three concepts. In creation, there is an order determined by God's will, which is definitive in its form and perfect and represented by the natural world and man in his biological aspect. It is also possible to distinguish the order ruled by the principles of reason, freedom, and purpose, in which God reveals his will but also leaves space for its free acceptance and is represented by the personal world including man. The third form of the order established by God is a particular order in man, which is the law of his rational nature being at the same time innate, inviolable, and inalienable, as well as given to man as a person gifted with the free will and intelligence. There thus is a bond between the task given to man and his interior preparation for it. A significant role is here exercised by the term 'good will,' which is the moment of transition between this order as God's gift and as man's task. The will is an element of human sovereignty, but its goodness constitutes its aspect of being gifted and prepared by God.

In the title and the first words of the encyclical, there are two collocations of the word "peace," namely, "peace between nations," and "peace on earth," which seem to have a crucial meaning for the content of the encyclical. According to the argument that the word "peace" refers to a desired but not yet realized state of affairs, the context of its use permits one to state that "peace between nations" refers to the definitive shape of the "order in social relations," as intended by God. For peace is the main subject of Pacem in terris, which sketches the principles for its attainment. The collocation "peace on earth" refers to the definitive shape of the entirety of God's plan for creation, which is already realized on every level, and on account of its eschatological nature, is unchangeable and eternal. Because the natural order and the order within man have their stable form because of God's will, it seems reasonable 
to assume that the accomplishment of this order in social relations and the peace between the nations is the final stage of building this eschatological peace on earth. The theological vision of Pope John XXIII passes from a protological analysis of theological anthropology and concludes with political theology. In this way, he legitimizes the latter. In his teaching, peace, as the work of God based on the order established by Him, must be completed in the order of social relations. It was given to man as a task by God, who at the same time prepared him for it through the law of rational human nature and binds him by this law.

The images of God and the Church, which appear in the encyclical, are little developed and much simplified. The wealth of these images in the Holy Bible and the Sacred Tradition remains unused and it seems to be intentional, because of the purpose of the document. However, it can cause a wrong and dangerous impression that God in John XXIII's thought is reduced to just a few aspects. To avoid that, it is necessary to read the encyclical in the wide context of previous documents of Church teaching, to which it refers multiple times, as well as the purposes which it fulfills in the international situation. The God establishing order and making peace is not only an idea presented on the first few pages of the encyclicals, but He remains an active personal force, whose action is considered on every stage of this papal teaching. It means that an effort made by man to make peace in social relations, and thus peace on earth, is filled with God's constant assistance, which can be a topic for exclusively theological research. An important theological conclusion is teaching that: "And so, dearest sons and brothers, we must think of human society as being primarily a spiritual reality," ${ }^{20}$ a conclusion thus referring to the supernatural world. The Pope quite clearly refers to four values: truth, justice, freedom, and love, which are described in their social aspect in Pacem in terris. They are also a kind of argument for the spiritual character of human society. These four words come from God and they not only create society but also make its order and elevate it through its fulfillment in spiritual values and reading it in the context of supernatural reality. ${ }^{21}$ A properly ordered society starts to understand the meaning of these spiritual values and brings it about that people start to discover their connection with the personal God, as well as the relationship with Him as the foundation of their lives and

\footnotetext{
${ }^{20}$ Jan XXIII, Pacem in terris, 36.

${ }^{21}$ Ibidem, 35.
} 
their coexistence with others. ${ }^{22}$ The Pope goes beyond legal categories and focuses on the spiritual transformation of peoples' hearts, whose foundation is the universal desire of peace, which is described as the greatest desire of the whole human family. In this context, Jesus Christ is called the maker of peace, and the Pope, His Vicar, whose task is to express this desire and not to hesitate to ask and beg in His name both individuals and rulers not to spare their efforts for the cause of global peace. The Pope assures his prayers, which expresses his faith that God actively cooperates with people in the task He gave them. ${ }^{23}$ This permits giving the construction God's order on earth to be given both a christological and ecclesiological element at the same time. Similarly, the cause of global peace is not possible to attain without God's assistance, which is justified by the fact that a world filled with peace is a reflection of the Kingdom of God. The Pope points Christ Himself as the surest source of peace. According to St. Paul, He is described as peace itself and its herald, who unifies humanity and disrupting interpersonal hostility. The peace brought by Christ is certain because it does not come from this world and therefore it can strengthen men's hearts filled with fear and lead them toward trust. ${ }^{24}$ Considering the examples above, there is no doubt that God constantly cares about the order He established and guarantees the realization of the tasks He gave to man. His presence is multiform but is also revealed as very orderly. That is why God reveals himself as the source of every element which orders the life of man, as the ultimate goal toward which man strives, but also as the providential guardian, who constantly secures his work.

The fifth chapter of the encyclical, "Pastoral exhortations," introduces an entire new context to the teaching of John XXIII. The widely discussed principles of building the global order in social relations is complemented with a direct call to the Christians and describing their part in the process of building peace. In the light of their faith, they are additionally called to join the building of God's order on earth and to cooperate with all people in this matter. At the same time, Christians formed by Christian revelation receive their own task, which is that of shaping of the social order, such that it be beneficial not only for the temporal but also the supernatural goals. ${ }^{25}$ The

\footnotetext{
${ }^{22}$ Ibidem, 45.

${ }^{23}$ Ibidem, 119.

${ }^{24}$ Ibidem, 167-71.

${ }^{25}$ Ibidem, 146.
} 
tension between being in the world and being attracted by that what is beyond it, strongly affects all the pastoral exhortations in Pacem in terris. John XXIII emphasizes that Christians cannot be indifferent to global efforts which have as their goal the realization of the universal common good and should be prepared and feel doubly obliged by it.

John XXII in Pacem in terris often quotes his predecessors of the throne of Saint Peter, especially the popes since Leo XIII. In the footnotes present throughout the text of the encyclical, the Pope refers to the documents and speeches of Leo XIII, Benedict XV, Pius XI, Pius XII, and even his own. Through such multiple references to the teaching of previous popes, John XXIII clearly emphasizes the continuity of Magisterium, as well as that the content of Pacem in terris is nothing new in the Church's social teaching but follows directly from its previous forms and express its continuous evolution. The encyclical Pacem in terris is both a summary and synthesis of the previous teaching of the Church on this matter. It is also a starting point for further development in the face of new challenges. ${ }^{26}$

The Christmas speech of Pius XII from 1942 is not only the most often cited in Pacem in terris but is also considered as particularly important, because of its character of a declaration of human rights and a manifesto of Christian personalism. ${ }^{27}$ Pius XII at length explains why, as the voice of the Church, he decides to express its position in social matters and justifies this theologically, which is very meaningful for comprehending the teaching of his successors. His perspective is both a radically pessimistic diagnosis of the condition of humanity and a radically optimistic conviction that God in His Son brings all the solutions and answers. In Pius XII's theology from the Christmas speech of 1942, there is no place for solely secular ways of improving man's living situation, but he still tries to construct them for further stages. This attitude is explained by the biblical fragment: "I feel sorry for these people" (Matthew 8:2), which he treats as a moral command, according to which the Church cannot be deaf to the cries directed to it by various social groups.

\footnotetext{
${ }^{26}$ Józef Majka, "Komentarz do encykliki Jana XXIII 'Pacem in terris,"” in Jan XXIII, Pacem in terris (Wrocław: Wydawnictwo Archidiecezjalne, 1997), 85-6.

${ }^{27}$ Strzeszewski, Katolicka nauka społeczna, 283.
} 


\section{PROSPECTS OF COOPERATION BETWEEN THEOLOGY AND LAW}

In the light of what has been discussed above, the encyclical Pacem in terris has both considerable legal and theological value. It remains connected with the legislative activity of the international community, as well as the tradition of the social teaching of the Church in the last century. This brings it about that the document of John XXIII is the perfect forum for searching for points of contact between theology and law.

To understand how legal and theological elements coexist in the encyclical, it is first necessary to answer the question as to which of them possesses a greater quantity. It is possible to say that the encyclical of John XXIII is a mostly legal document, which also contains less numerous elements, uniquely in the realm of theology. This conclusion leads to examining the way the Pope supplements his legal considerations with theological elements and what system is hidden behind this. It seems that the Pope has his method of using categories that can be read equivocally either as secular or temporal, based on the philosophy of law, or as spiritual, supernatural, based on theology. A very important role is played by the term "all men of good will" in the title of the document. It is the first document of the official teaching of the Church, which in its message goes beyond the community of baptized and is directed to all men who want to accept it. This choice of recipients corresponds with the above mentioned method of using words in their equivocal secular-spiritual context. Each recipient receives a different message in the encyclical. Humanity in general can receive valuable exhortations for building the social order inspired by natural law and the concept of human dignity. In turn, a wider theological context is presented to Christians, namely, the divine origin of the social order and the addendum with pastoral exhortations. One message can have both a wider and narrower interpretation, depending on the recipients. This allows the Successor of Saint Peter to remain faithful to the evangelical mission of "strengthening brothers in the faith," and at the same time play the new role of the shepherd whose flock is all of humanity. This new qualification of Peter's ministry receives two fundamental and strongly connected reference points: Christ and peace. The latter one is what unifies humanity most closely because it is its greatest desire. For the sake of the bond between peace and God's order and mission of Christ, this can be the perfect point of contact for temporal matters regulated by law and supernatural concerns, which are the subject of theology. 
One of the key topics which appear in Pacem in terris and has this equivocal meaning is "human family." In the context of this equivocal teaching, the human family reveals itself as both a factual reality and a task. This reveals two alternative models for the unity of humanity, namely, natural and ecclesial unity. The first is based on human nature and its origin is from God, and the second is based on the redemption of humanity by Jesus Christ. They have a complementary character as two ways directing to a common goal and have the shape of accomplishing the universally desired peace on earth as well as the unity of mankind in Christ, who Himself is peace. This whole system of teaching, created and used by the John XXIII, directed to these two different recipients, is explained in the fifth chapter of the encyclical, "Pastoral exhortations." These exhortations are directed primarily to the faithful of the Catholic Church, but at the same time he seems to explain to Christians their role in building social relations. It is expected from Christians that, because of the value of supernatural goods (as is well-known to them) and the love which they should have for all people, they not only focus on building ecclesial unity but also cooperate with "all men of good will" on the level of building peace on earth. Both levels are established by the God, to both $\mathrm{He}$ called humanity, and on both He plans to unify them, because peace on earth can ultimately be the work only of Christ, the Prince of Peace. The task of His Vicar is to do everything in his power to lead the world and the Church to this peace.

The way in which John XXIII describes his vision of the order of social relations constitutes a well-thought system, which reveals a few key observations. Its most important feature is the manner in which the Pope communicates his teaching, which is placed at the intersection of the law and theology, and this has its methodological justification. Six such features can be distinguished, whose proposed names are: cognitive realism, universal concepts, universal themes, social efficacy, legal naturalism, and mutual inspiration. These characteristics can be divided between those which witness to the openness of theology to law, as well as those which create the space for the openness of law to theology. The first feature of that what can be described as legal language is cognitive realism. This means the Pope's focusing on obvious, easily noticed facts as the foundation of the solutions to be implemented. The obviousness of the mentioned facts makes it happen that the system is not far from reality but strongly rooted in it. Theology reveals itself as more open because it resigns as it were from dialogue based on facts of a supernatural character for arguments for the solutions to be implemented. The second feature of John XXIII's legal language is his frequent use of 
legal terms (and hence universal). There is no doubt that legal order is the main topic of the document. The Pope's use of natural language for the legal context creates space for interdisciplinary dialogue. The third feature of the legal language used in Pacem in terris is the Pope's exposition of universal themes. The first of them is the accent placed on man himself. Another theme expounded by the Pope is peace as the universal desire of humanity. Peace is the justification, rooted deeply in the international situation of that time, for creating guarantees for obeying laws and performing duties, as well as building order on every level of social life. It is the very centre of all the thoughts in Pacem in terris. The last strongly emphasized theme of the encyclical is the human family. The Pope treats it as a factual reality and at the same time presents it as a goal to accomplish, motivated by the universal desire of peace described previously. The whole teaching of John XXIII concentrates on proving that all them are deeply connected to each other and called to the realization of this unity by its establishment in their relations and the guarantee of the commonly desired peace. The fourth feature of the legal language used by the Pope is social efficacy. He emphasizes that proposed solutions need to be effective to truly perform their guarantee function. Independent of whether this teaching has a more theological or philosophical and legal character, it ought to primarily have an effective impact on the order of social relations. The fifth feature is legal naturalism, which means using philosophical and legal argumentation. The quality of the statutory law depends on the quality of these philosophical foundations. That is why John XXIII uses the foundation of natural law, which is respected by the Church. The sixth and last feature used by the Pope in his use of legal language is constant mutual inspiration in relation to the legislative activity of the world-wide community of nations. John XXIII seems to be inspired by the Universal Declaration of the Human Rights, whose importance he emphasizes in Pacem in terris, but he also supplements the considerations about human rights made all over the world by the insights taken from the tradition of the social teaching of the Church. ${ }^{28}$

The goal of the Church and the United Nations are, in general, the same. Both communities in the time of John XXIII directed their efforts to the unification of humanity, the establishment of universal peace and the security of the good of man on account of his innate, inviolable, and inalienable dignity. ${ }^{29}$

\footnotetext{
${ }^{28}$ Ibidem, 143.

${ }^{29}$ Ibidem, 9.
} 
The difference between the Church and the United Nations can be reduced to the acceptance of the existence of the supernatural order, which has its impact on every aspect mentioned above. The United Nations wants to unify humanity by the system of international obligations, cooperation between states in every aspect, as well as the promotion of common values, and whose goods secured in this manner have a temporal character. ${ }^{30}$ The Church in turn in all its actions maintains its stable reference to God, whose sacred will it fulfills. ${ }^{31}$ Because of that, the unification of humanity to which it is directed has primarily the character of a religious unification, what means that all need to hear the Good News about Christ and gather around Him as the sheep around their shepherd. ${ }^{32}$ This unification presumes the peace, which is Christ himself, from whom it originates and then connects it to the universal dominion of truth and love. ${ }^{33}$ The goods protected by the Church in this way have supernatural character and are connected to the spiritual character of man and his eternal destination.

It is necessary to remember that the Church, besides the supernatural order, functions also in the temporal order. Holding this in consideration, the Church supports the efforts of the world-wide community of nations in the affirmation and explanation of human rights, as well as in its legislative activity, which best protects the broadly understood good, universal peace and the integration of all people. It uses the language, vocabulary, and philosophical and legal categories of this community. It also speaks to it on the ground of commonly accepted, even if differently interpreted, conception of the natural law in the concept of human rights. It is worth noting this context, which takes an intermediate place between the internal and external engagement of the Church. This context is the pastoral activity directed to its secular members, who are supposed to become, as Christians living in the world, mediators of the unity of people, which is achieved within the Church, and which humanity wants to achieve by temporal methods. Secular Christians are formed by truth and love, so they can protect the meaning of spiritual goods in the legal order of

\footnotetext{
${ }^{30}$ Karta Narodów Zjednoczonych [Charter of the United Nations], accessed June 8, 2020, https://sip-1lex-1pl-1000019oh351e.buhan.kul.pl/\#/act/16779385/8469/karta-narodow-zjednoczonychstatut-miedzynarodowego-trybunalu-sprawiedliwosci-i-porozumienie...?keyword=Karta\%20Narod\%

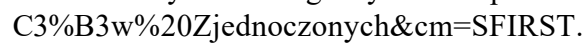

${ }^{31}$ Catechism of the Catholic Church (further cit. CCC), 763-766, https://www.vatican.va/archive/ ENG0015/ INDEX.HTM

${ }^{32} \mathrm{CCC}^{-} 772-3$.

${ }^{33}$ CCC 2305.
} 
states and international organizations. Due to this, they can act directly on both levels of achieving unity, peace and the common good of all people. With this in mind, the Popes include in their encyclicals elements of theological argumentation and pastoral exhortations, so that Christians who read them would understand the value of their engagement in the world and remain permanently bound to this within their hearts, being aware that they are contributing to the fulfillment of God's will.

It is also necessary to note its eschatological context. The Church makes a pilgrimage to the end times, which bring the fullness of unity, peace and good to everyone, who attain salvation in the Christ. ${ }^{34}$ The universal desire for peace and progressive international integration is the expression of the common expectations of humanity. It gives a completely new outlook on the activity of the world-wide community of nations, which, as it progresses toward its eternal destiny looks like the Church. The task of the latter is to support these universal aspirations, encourage them, and discern their significance in the light of faith.

The above ecclesiological observations have a significant methodological value for research at the intersection of theology and law. Theology, in service of the Church's teaching, must take into account its essence and mission. For since the Church undertook such an open and broad dialogue with the international community, theology needs to remember that the Christian concept of law should consider the temporal good of man, the communicational character of the Church's activities in the world, and the whole context of the supernatural order, whose source, centre and purpose is Christ himself. Only the consideration of these three spaces will permit the efficacy of theology in fulfilling the Church's task, which it has discovered in the 20th century and the understanding of which it continues to deepen.

\section{BIBLIOGRAPHY}

Jan XXIII. Encyclical Pacem in terris on Establishing Universal Peace in Truth, Justice, Charity, and Liberty. April 11, 1963. http://www.vatican.va/content/john-xxiii/en/encyclicals/documents/ hf_j-xxiii_enc_11041963_pacem.html.

Karta Narodów Zjednoczonych [Charter of the United Nations]. Accessed June 8, 2020. https:// sip-1lex-1pl-1000019oh351e.buhan.kul.pl/\#/act/16779385/8469/karta-narodow-zjednoczonychstatut-miedzynarodowego-trybunalu-sprawiedliwosci-i-porozumienie...?keyword=Karta\%20Narod $\% \mathrm{C} 3 \% \mathrm{~B} 3 \mathrm{w} \% 20 \mathrm{Zjednoczonych} \& \mathrm{~cm}=$ SFIRST.

\footnotetext{
${ }^{34}$ CCC $1042-5$.
} 
Kelly, John N.D. Encyklopedia papieży. Translated by Tadeusz Szafrański. Warszawa: Państwowy Instytut Wydawniczy, 2006.

Lusawa, Roman. "Encyklika 'Pacem in terris' - głos Kościoła katolickiego w sprawie pokoju z 11 kwietnia 1963 roku." Rocznik Naukowy Wydziału Zarzadzania w Ciechanowie 4, no. 1-4 (2010): 103-18.

Majka, Józef. "Komentarz do encykliki Jana XXIII 'Pacem in terris."” In Jan XXIII. Pacem in terris, 77-87. Wrocław: Wydawnictwo Archidiecezjalne, 1997.

Powszechna Deklaracja Praw Człowieka [Universal Declaration of Human Rights]. Accessed June 8, 2020. https://www.unesco.pl/fileadmin/user_upload/pdf/Powszechna_Deklaracja_Praw Czlowieka.pdf

Sobański, Remigiusz. Nauki podstawowe prawa kanonicznego. Vol. 2. Teologia prawa kościelnego. Warszawa: Wydawnictwo Uniwersytetu Kardynała Stefana Wyszyńskiego, 2001.

Sobański, Remigiusz. Nauki podstawowe prawa kanonicznego. Vol. 2. Teologia prawa kościelnego. Warszawa: Wydawnictwo Uniwersytetu Kardynała Stefana Wyszyńskiego, 2001.

Strzeszewski, Czesław. Katolicka nauka społeczna. Warszawa: Wydawnictwo ODiSS, 1985.

Wołodkiewicz, Witold. “'Ius et lex’ w rzymskiej tradycji prawnej.” Ius et Lex no. 1 (2002): 51-61.

\section{RELACJA MIĘDZY TEOLOGIĄ A PRAWEM NA PODSTAWIE ENCYKLIKI PACEM IN TERRIS JANA XXIII}

Streszczenie

Celem niniejszego artykułu jest wyciagnięcie wniosków o charakterze prawnym i teologicznym. Pierwszy podpunkt, który przedstawia prawną wartość i społeczno-polityczny kontekst nauczania papieskiego, pozwala na stworzenie podstaw dla dalszych teologicznych refleksji. Drugi podpunkt pozwala na wyodrębnienie teologii encykliki oraz jej znaczenia dla całości dokumentu. Ostatni podpunkt ujawnia, w jaki sposób prawne i teologiczne elementy przenikają się w tekście encykliki i jakie ma to konsekwencje dla eklezjologii i metodologii badań na styku teologii i prawa. Niniejszy artykuł przedstawia również wiele wspólnych punktów odniesienia dla teologii i prawa oraz podkreśla ich metodologiczną i wewnętrzną autonomię. Encyklika Pacem in terris Jana XXIII jest twórczą propozycją dla współpracy między teologią a prawem, w ramach której papież kieruje się zasadą skuteczności w postaci pragnienia, żeby stworzony przez niego katalog był nie tylko teoretyczny, ale faktycznie przestrzegany. Jego nauczanie koncentruje się na tematyce pokoju jako przede wszystkim prawnej kategorii, a zatem decydującej dla sprawiedliwego charakteru prawa jako takiego. Ze względu na związek między pokojem, Bożym porządkiem i misją Chrystusa istnieje przestrzeń wspólna dla spraw doczesnych regulowanych przez prawo oraz nadprzyrodzonych, które są przedmiotem teologii. Istnieją dwa alternatywne modele jedności ogólnoludzkiej: naturalny i kościelny. Mają one komplementarny charakter jako dwie drogi prowadzące do wspólnego celu i przyjmują postać dążenia do powszechnie upragnionego pokoju na ziemi i zjednoczenia ludzkości w Chrystusie, który jest samym pokojem. Papież używa języka prawnego, który charakteryzuje się otwartością teologii na prawo i odwrotnie. Do jego cech należą: realizm poznawczy, uniwersalne terminy, uniwersalne tematy, skuteczność społeczna, naturalizm prawny oraz wzajemna inspiracja.

Słowa kluczowe: prawo; teologia; pokój; Jan XXIII; Pacem in terris; metodologia. 